\title{
GPC5 Gene
}

National Cancer Institute

\section{Source}

National Cancer Institute. GPC5 Gene. NCI Thesaurus. Code C88170.

This gene plays a role in cellular interactions with proteoglycans. 